\title{
Synergetic anticancer activity of gold porphyrin appended to phenyl tin malonate organometallic complexes
}

Christophe Nguyen, ${ }^{a \#}$ Isabelle Toubia, ${ }^{\text {bc }}$ Stéphane Diring, ${ }^{b}$ Kamel Hadj-Kaddour, ${ }^{a}$ Magali Gary-Bobo, ${ }^{* a}$ Marwan Kobeissi, ${ }^{* c}$ Fabrice Odobel ${ }^{* b}$

aIBMM, Univ Montpellier, CNRS, ENSCM, Montpellier, France. E-mail: magali.garybobo@inserm.fr

${ }^{b}$ CEISAM, Chimie Et Interdisciplinarité, Synthèse, Analyse, Modélisation, CNRS, UMR CNRS 6230, UFR des Sciences et des Techniques; 2, rue de la Houssinière - BP 92208; 44322 NANTES Cedex 3 (France). E-mail:Fabrice.Odobel@univ-nantes.fr

'Laboratoire Rammal Rammal, Equipe de Synthèse Organique Appliquée SOA, Université Libanaise, Faculté des Sciences 5, Nabatieh, Liban. E-mail: $\underline{\text { mkobeissi@ul.edu.lb }}$

\section{\#These authors contributed equally to this study.}

\begin{abstract}
The discovery of novel anticancer chemotherapeutics is fundamental to treat cancer more efficiently. Towards this goal, two dyads consisting of a gold porphyrin appended to organotin(IV) entities were synthesized and their physicochemical and biological properties were characterized. One dyad contains a gold porphyrin connected to tin(IV) cation via a malonate and two phenyl ligands (AuP-SnPh $\mathbf{2}$ ), while the second contains two tin(IV) cations each chelated to one carboxylic acid group of the malonate and three phenyl ligands (AuP$\mathrm{Sn}_{2} \mathrm{Ph}_{6}$ ). The mode of chelation of $\mathrm{Sn}(\mathrm{IV})$ to the malonate was elucidated by IR spectroscopy and ${ }^{119} \mathrm{Sn}$ NMR. In the solid state, the complexes exist as coordination polymers in which the tin is penta-coordinated and bridged to two different malonate units. In solution the chemical shifts of ${ }^{119} \mathrm{Sn}$ signals indicate that the tin complexes are in the form of monomeric species associated with a tetra-coordinated tin cation. The therapeutic potential of these new compounds was assessed by determining their cytotoxic activities on human breast cancer cells (MCF-7) and on healthy human fibroblasts (FS 20-68). The study reveals that the dyads are more potent anticancer drugs than the mixture of their individual components (gold porphyrin and reference tin complexes). Therefore, the covalent link of organotin complexes to a gold porphyrin induces a synergistic cytotoxic effect. The dyad AuP-SnPh presents high cytotoxicity $(0.13 \mu \mathrm{M})$ against MCF-7 along with a good selectivity for cancer cells versus healthy cells. Finally, it was also shown that the dyad AuP-S $\mathbf{n}_{\mathbf{2}} \mathbf{P \mathbf { P } _ { 6 }}$ exhibits a very high anticancer activity $\left(\mathrm{LC}_{50}=0.024 \mu \mathrm{M}\right)$, but the presence of two tin units induces a strong cytotoxic on healthy cells too $\left(\mathrm{LC}_{50}=0.032 \mu \mathrm{M}\right)$. This study underscores, thus, the potential
\end{abstract}


of the association of gold porphyrin and organotin complexes to develop anticancer metallodrugs.

\section{Introduction}

Cancer remains one of the most important causes of mortality in the world. The development of new and more selective anticancer drugs constitutes, therefore, a priority to strive against this disease. Organometallic compounds are attractive weapons against cancers and they have, so far, contributed towards the development of efficient modern medicinal anticancer treatments. For examples, the famous cisplatin and its derivatives, carboplatin and oxaliplatin are potent cytotoxic metallodrugs, which have been routinely used for decades in clinical treatment for various types of cancer (prostate, testicle, ovary, bladder and lung). ${ }^{1}$ The development of resistance mechanism of certain cancers and the high toxicity for healthy cells leading to important secondary side effects prompted coordination chemists to investigate the anticancer activity of other families of complexes with fewer side effects. Towards this goal, many coordination and organometallic compounds with rhenium, ${ }^{2-3}$ ruthenium, ${ }^{4-5}$ iron, $^{6}$ titanium, ${ }^{7}$ rhodium, ${ }^{8}$ iridium, ${ }^{3,8}$ osmium, ${ }^{3}$ gold ${ }^{9}$ and $\operatorname{tin}^{10}$ metals were prepared and their cytotoxic activities were evaluated. More specifically, gold porphyrins show valuable anticancer activities as they represent stable $\mathrm{Au}(\mathrm{III})$ complexes in physiological environment. ${ }^{9,11-12}$ Indeed, Che and co-workers reported in 2003, that gold meso tetrakis-phenyl porphyrin (AuTPP) was a powerful cytotoxic drug against several cancer cells lines. ${ }^{12-15}$ Subsequent investigations on gold porphyrins support a mode of action involving the heat-shock protein HSP60. ${ }^{16-18}$ On the other hand, tin organometallic compounds, particularly with carboxylate and mercapto ligands, present promising cytotoxic activity without resistance development found with classical chemotherapeutics. $^{10,19}$ Like platinum metallodrugs, it is accepted that organotin compounds directly interact with DNA, causing cell death either by apoptotic or necrotic mechanisms. ${ }^{19}$ Previous works have been devoted to free base porphyrin/tin complex conjugates, but free base porphyrin has little anticancer activity and is very hydrophobic like the tin complex. ${ }^{20-22}$ In this study, a cationic gold porphyrin, which is less hydrophobic than the corresponding free base and whose cytotoxic activity toward cancer cells was clearly evidenced, ${ }^{12,14-15}$ was covalently appended to a tin malonate complex in order to investigate the possibility of amplifying the chemotherapeutic activity and the selectivity of these conjugates (Chart 1). One conjugate contains one tin organometallic moiety bearing two phenyl groups in its coordination sphere $\left(\mathrm{SnPh}_{2}\right)$, while in the second conjugate, the tin is bound to three phenyls $\left(\mathrm{SnPh}_{3}\right)$. Phenyl was selected as organometallic moiety around tin(IV), because it was shown in previous studies, that this type of motifs provides the highest anticancer activity. ${ }^{23-24}$ On the other hand, malonic acid ligand was chosen to append tin(IV) cation because as a hard Lewis acid it has a strong affinity to carboxylate. ${ }^{25-26}$ In addition, it is known that tin(IV) complexes present anticancer activity and particularly those with carboxylate ligands. ${ }^{10,27}$ 


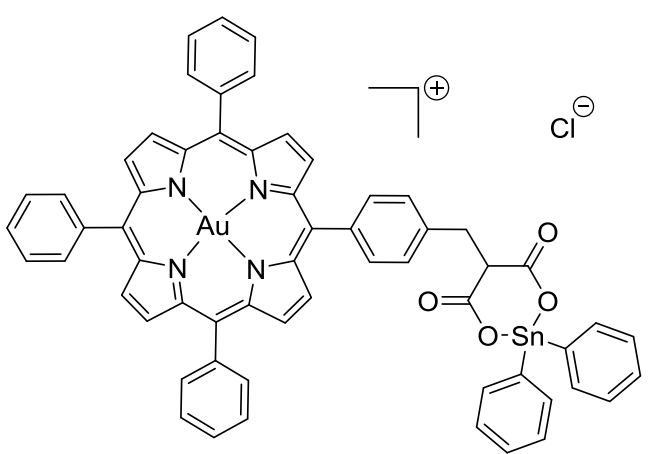

AuP-SnPh

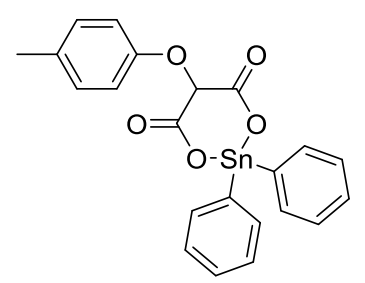

$\mathrm{SnPh}_{2}$
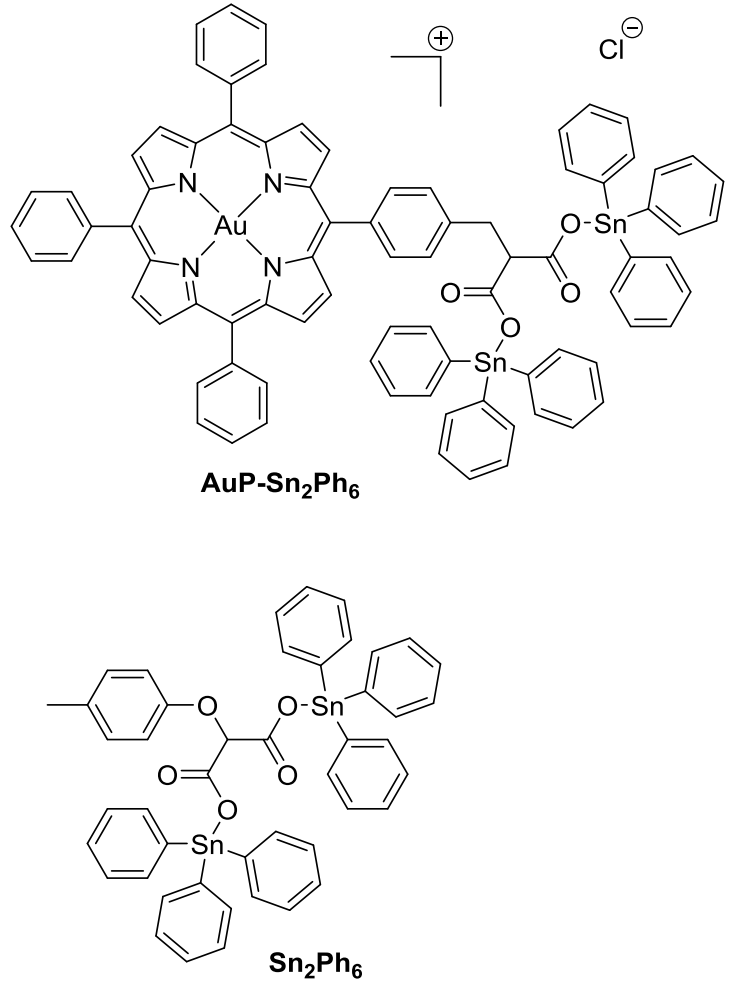

Chart 1. Structures of the compounds investigated in the study.

Overall, this study shows that the two gold porphyrin-tin dyads AuP-SnPh $\mathbf{P h}_{\mathbf{2}}$ and $\mathbf{A u P -} \mathbf{-} \mathbf{S n}_{\mathbf{2}} \mathbf{P} \mathbf{h}_{\mathbf{6}}$ exhibit superior cytotoxicity compared to the equimolar mixtures of their individual components AuTPP-Malonic acid (Porphyrin 2) and $\mathbf{S n P h} \mathbf{P h}_{\mathbf{2}}$ or $\mathbf{S n}_{\mathbf{2}} \mathbf{P h}_{\mathbf{6}}$. In addition and very interestingly, they display higher level of cytotoxicity toward MCF-7 carcinoma cell line than healthy cells, underscoring thus the potential of these associations to develop anticancer metallo-drugs.

\section{Synthesis of the compounds}

The synthesis of the reference tin compounds $\left(\mathbf{S n P h}\right.$ and $\left.\mathbf{S n}_{\mathbf{2}} \mathbf{P h} \mathbf{h}_{6}\right)$ is illustrated in Scheme 1. The di-carboxymalonate $p$-cresol 1 ligand was prepared as previously described. ${ }^{28}$ The dicarboxylato tin complexes $\mathbf{S n P h}$ and $\mathbf{S n}_{\mathbf{2}} \mathbf{P h}_{\mathbf{6}}$ were respectively obtained in $71 \%$ and $93 \%$ yield by initial deprotonation of the carboxylic acid groups with triethylamine before being reacted with the tin phenyl precursor containing one or two chloro ligands. ${ }^{28}$ 


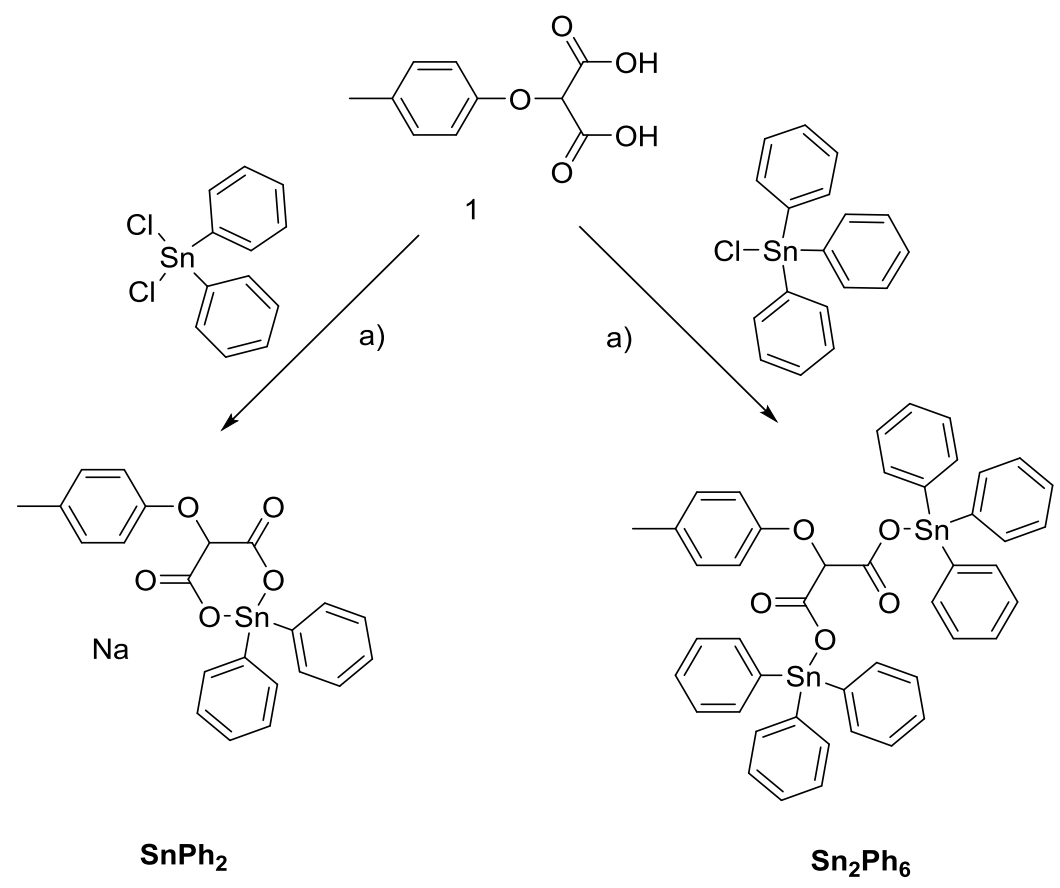

Scheme 1. Synthetic route for the preparation of the reference tin complexes $\mathbf{S n P h}$ and $\mathbf{S n}_{\mathbf{2}} \mathbf{P h}$. Reagents and conditions: a) THF, TEA, RT, $12 \mathrm{~h}, 71 \%$ for $\mathbf{S n} \mathbf{P h}_{\mathbf{2}}$ and $93 \%$ for $\mathbf{S n}_{\mathbf{2}} \mathbf{P h}$.

The preparation of the dyads made of gold porphyrin/tin complex required the porphyrin 2 as key intermediate, which was synthesized as previously described (Scheme 2). ${ }^{29}$ The introduction of the tin complex was accomplished with the same strategy as that described for the reference complexes. The conjugates were obtained in $98 \%$ and $80 \%$ yields for AuP$\mathrm{SnPh}_{\mathbf{2}}$ and $\mathbf{A u P}-\mathbf{S n}_{2} \mathbf{P h}_{6}$ respectively. The complexes were satisfyingly characterized by proton NMR, high resolution mass spectrometry and elementary analyses. The dyads AuP-Sn $\mathbf{P h}_{\mathbf{2}}$ and AuP-Sn $\mathbf{P h}_{6}$ were soluble in DMSO, THF, DMF, chloroform and acetone. 


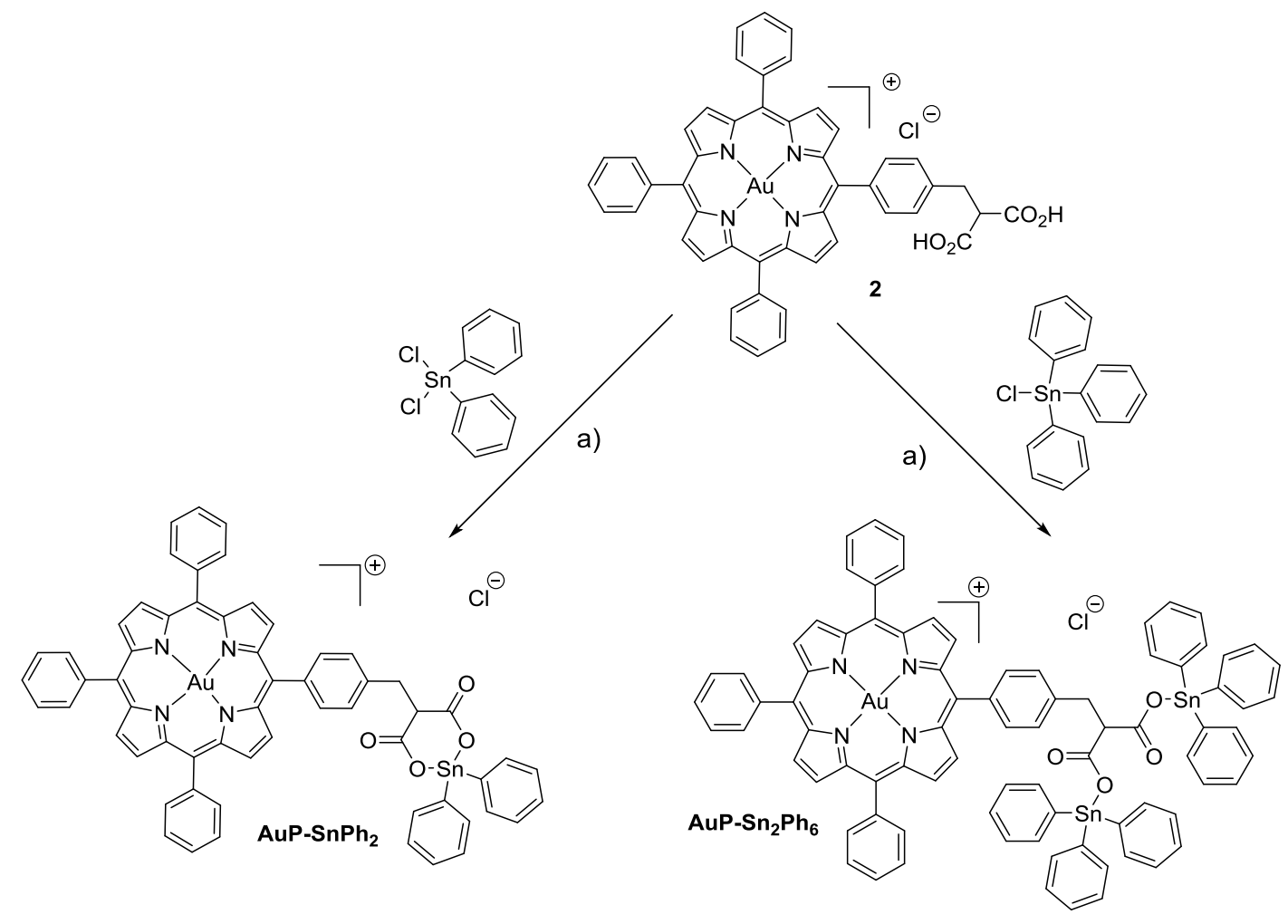

Scheme 2. Synthetic route for the preparation of the dyads composed of gold porphyrin linked to tin complex. Reagents and conditions: a) THF, TEA, RT, 12h, 98\% for AuP-SnPh $\mathbf{A n d}_{\mathbf{2}}$ and $80 \%$ for AuP-Sn ${ }_{2} \mathbf{P h}_{6}$.

\section{UV-Vis Electronic Absorption Spectra}

The absorption spectra of the gold porphyrin/tin complex dyads along with that of the reference gold tetrakis phenyl porphyrin (AUTPP) recorded in dichloromethane are shown in Figure 1, and the spectroscopic data are gathered in Table 1. The spectra of the dyads are essentially dominated by the transitions of the gold(III) porphyrin unit, since the Sn complex does not exhibit any absorption band in the visible region (Figure S5) and there is no communication between the porphyrin and the tin complex. This is consistent with previously published conjugates composed of a dye appended to a complex with non- $\pi$ conjugated spacer. ${ }^{29-31}$ More specifically, the dyads exhibit the characteristic absorption bands of gold tetrakisaryl porphyrins, with a blue shift of Soret (at $412 \mathrm{~nm}$ ) and the Q-bands (around $530 \mathrm{~nm}$ ) owing to the back bonding between gold(III) and the porphyrin ligand, which stabilizes the HOMO level and increases the HOMO-LUMO gap with respect to that of the parent free base or zinc porphyrins. ${ }^{32}$ Unsurprisingly, the presence of the appended tin complex does not alter the spectrum of the gold porphyrin owing to the deconjugation induced by the methylene spacer between the porphyrin and the Sn complex. 


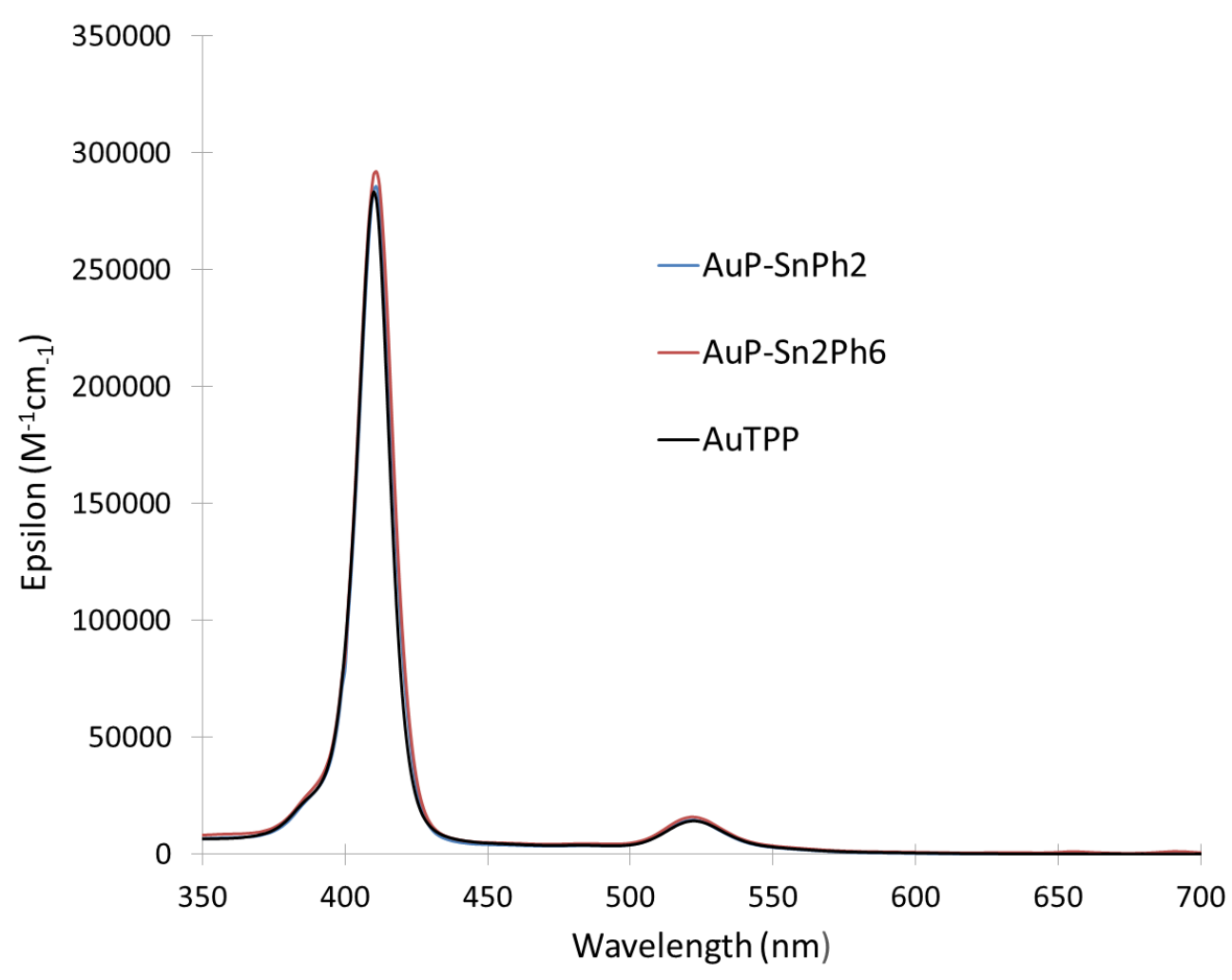

Figure 1. Absorption spectra of the porphyrin derivatives recorded in dichloromethane.

Table 1. Maximum absorption wavelengths and molar extinction coefficients of the porphyrins recorded in dichloromethane at room temperature.

\begin{tabular}{|l|l|}
\hline Compound & $\lambda_{\mathrm{abs}} / \mathrm{nm}\left(\log\right.$ ? $\left./ \mathrm{M}^{-1} \mathrm{~cm}^{-1}\right)$ \\
\hline AuP-SnPh & \\
\hline AuP-Sn $\mathbf{P h}_{\mathbf{6}}$ & $412(5.44) ; 532(3.98)$ \\
\hline AuTPP & $412(5.45) ; 529(4.11)$ \\
\hline
\end{tabular}

\section{Infra-Red and ${ }^{119}$ Sn NMR spectroscopic studies}

Carboxylate ligand can chelate tin(IV) cation according to several potential binding modes (Figure 2).$^{10,33-34}$ In solid state, tri-organo tin(IV) complexes are usually polymeric compounds with cis-trigonal bipyramidal geometry having five-coordinate tin sites under the bridging mode (type A). 

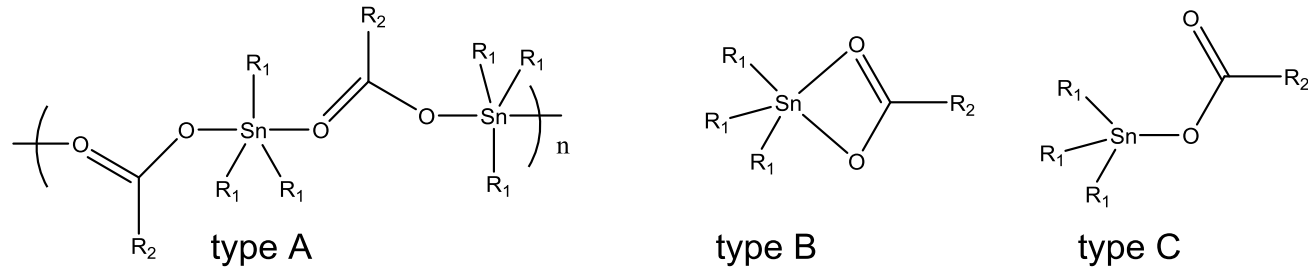<smiles>[R]C(=O)O[Sn]([R1])([R7])OC([R])=O</smiles>

type D

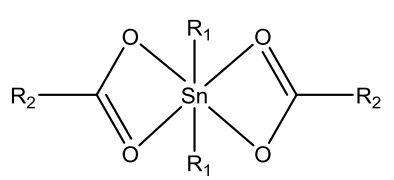

type $\mathrm{E}$

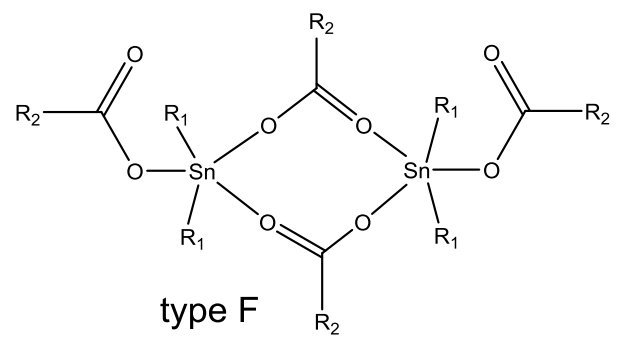

type $\mathrm{F} \quad \mathrm{R}_{2}$

Figure 2. Illustration of the main binding modes of tri-organo tin(IV) and di-organo tin(IV) complexes with carboxylate ligand.

Particularly in solution, the complexes can exist as monomers either under a five-coordinate chelating bridged mode (type B and E) or as four-coordinated tin with carboxylate acting as a monodentate ligand (types $C$ and D). ATR-IR and ${ }^{119}$ Sn NMR spectra can be used a tools to diagnose the mode of coordination of tin complexes. ${ }^{26,33,35-36}$ More specifically, concerning IR spectroscopy, the binding mode can be deduced from the wavenumber difference $(\Delta v=$ $\left.v_{\text {as }}-v_{s}\right)$ between the carboxylate antisymmetric $\left(v_{a s}\right)$ and symmetric $\left(v_{s}\right)$ stretches. $^{34,37-38}$ If this difference is larger than $250 \mathrm{~cm}^{-1}, \operatorname{tin}(\mathrm{IV})$ is involved in a tetrahedral geometry (type $C$ and $D$ binding modes), while values between 250 and $150 \mathrm{~cm}^{-1}$ indicate a bridging structure (types A and F). When $\Delta v$ is lower than $150 \mathrm{~cm}^{-1}$, then carboxylate is bidentate and binds to Sn(IV) under the bridged chelating mode (types B and E). The strong asymmetric stretching band of the carbonyl group in the acid form of compounds $\mathbf{1}$ and 2, situated around 1700 $\mathrm{cm}^{-1}$ has completely disappeared and is shifted to lower energy after the reaction with chloro phenyl tin derivatives, besides the strong stretching band of Sn-O linkage is clearly visible at $450 \mathrm{~cm}^{-1}$ for both $\mathbf{A u P - S n P h}$ and $\mathbf{A u P - S n _ { 2 }} \mathbf{P h}_{6}$ (Figures S1-S4 in ESI materials). These two features are supplementary indications that complexation of tin by the carboxylate has occurred. The wavenumber values of the stretching bands of the carboxylate before and after complexation of tin(IV) and the ${ }^{119} \mathrm{Sn}$ chemical shifts are gathered in Table 2 and the spectra are shown in Figures S1-S4 in ESI materials. The ${ }^{119} \mathrm{Sn}$ chemical shifts of the 
conjugates AuP-SnPh $\mathbf{P}_{2}$ and $\mathbf{A u P}-\mathbf{S n}_{2} \mathbf{P h}_{6}$ could not be determined owing to their insufficient solubility to record reliable NMR spectra.

Table 2. Wavenumber values of the stretching bands of the compounds recorded in the solid state by IR-ATR spectroscopy and ${ }^{119}$ Sn chemical shift $(\delta)$ recorded in THF solution.

\begin{tabular}{|c|c|c|c|c|c|}
\hline Compound & $\begin{array}{c}v(\mathrm{Sn}-\mathrm{O}) \\
\mathrm{cm}^{-1}\end{array}$ & $\begin{array}{c}v_{\text {as }}(\mathrm{OCO}) \\
\mathrm{cm}^{-1}\end{array}$ & $\begin{array}{c}v_{\mathrm{s}}(\mathrm{OCO}) \\
\mathrm{cm}^{-1}\end{array}$ & $\Delta v$ & $\begin{array}{c}\delta\left({ }^{119} \mathrm{Sn}\right) \\
\mathrm{ppm}\end{array}$ \\
\hline $\mathbf{1}$ & - & 1706 & 1399 & 307 & - \\
\hline $\mathbf{S n P h}_{\mathbf{2}}$ & 446 & 1592 & 1429 & 163 & -172 \\
\hline $\mathbf{S n}_{\mathbf{2}} \mathbf{P h}_{\mathbf{6}}$ & 453 & 1624 & 1428 & 196 & -226 \\
\hline $\mathbf{2}$ & - & 1726 & 1358 & 368 & - \\
\hline $\mathbf{A u P - S n P h}$ & 450 & 1598 & 1429 & 169 & n.r. \\
\hline AuP-Sn $\mathbf{P h}_{\mathbf{6}}$ & 450 & 1643 & 1428 & 215 & n.r. \\
\hline
\end{tabular}

n.r.= not recorded owing to insufficient solubility of the dyads for suitable ${ }^{119}$ Sn spectra

In the diphenyl tin(IV) compounds ( $\mathbf{S n P h}$ 列 $\mathbf{A u P - S n P h}$ ), the $\Delta v$ values are between 250 and $150 \mathrm{~cm}^{-1}$ indicating that in the solid state, these complexes are probably associated to form coordination polymer with carboxylate acting as bidentade ligand (type F) but in a bridged mode owing to the intramolecular nature of the two carboxylate groups of malonate. For the tri-phenyl tin(IV) compounds $\left(\mathbf{S n}_{\mathbf{2}} \mathbf{P h} \mathbf{h}_{6}\right.$ and $\left.\mathbf{A u P -} \mathbf{S} \mathbf{n}_{\mathbf{2}} \mathbf{P} \mathbf{h}_{6}\right)$, the $\Delta v$ values are between 250 and $150 \mathrm{~cm}^{-1}$ meaning that they also exist as coordination polymers (type A) in which the tin is penta-coordinated and bridged to two different malonate units. The chemical shifts $\delta\left({ }^{119} \mathrm{Sn}\right)$ of organo-tin compounds cover a broad range from $200 \mathrm{ppm}$ to -550 ppm. It has been shown that diphenyl tin(IV) are tetra-coordinated when $\delta\left({ }^{119} \mathrm{Sn}\right)$ is situated in the range of +30 to $-220 \mathrm{ppm}$, while penta-coordinated ones are situated between -250 ppm and -340 ppm. ${ }^{39}$ Consequently, compounds $\mathbf{S n P h}_{\mathbf{2}}$ and $\mathbf{A u P - S n P h}$ are most likely tetracoordinated in solution as the carbonyl dissociates and is probably replaced by a solvent molecule. On the other hand, $\delta\left({ }^{119} \mathrm{Sn}\right)$ of penta-coordinated trialkyl organotin of complexes lie in the range -100 to $-330 \mathrm{ppm}$, while tetra-coordinated are between +200 to $-60 \mathrm{ppm} .^{26,40}$ Since the chemical shifts of ${ }^{119} \mathrm{Sn}$ signal in reference complex $\mathbf{S n}_{\mathbf{2}} \mathbf{P h}_{\mathbf{6}}$ is $-226 \mathrm{ppm}$, it is concluded that this complex and most probably the parent compound AuP-Sn $\mathbf{P h}_{6}$ are pentacoordinated in solution.

\section{Biological tests}


In order to determine the therapeutic potential of these new compounds, the cytotoxic activity on human breast cancer cells (MCF-7) and healthy fibroblasts (FS 20-68) were studied. Figure 3 shown their semi logarithmic representations (Figure 3 ). The red curves correspond to the evolution of the percent of living cells in function of dyads concentrations

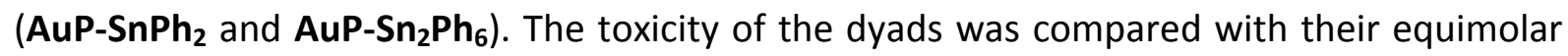
mixture of gold porphyrin $\mathbf{2}$ and the reference tin complex $\mathbf{S n P h}$ or $\mathbf{S n}_{\mathbf{2}} \mathbf{P h}_{\mathbf{6}}$ (blue curves). Towards this goal, cells were incubated $72 \mathrm{~h}$ in darkness, with increasing concentrations of each compound (from 0.01 to $100 \mu \mathrm{M}$ as final concentration). As shown in all cases, dyads were more toxic than mixtures whether it is $\mathbf{A u P - S n P h}$ or AuP-S $\mathbf{n}_{\mathbf{2}} \mathbf{P h}_{\mathbf{6}}$ and whether it is on
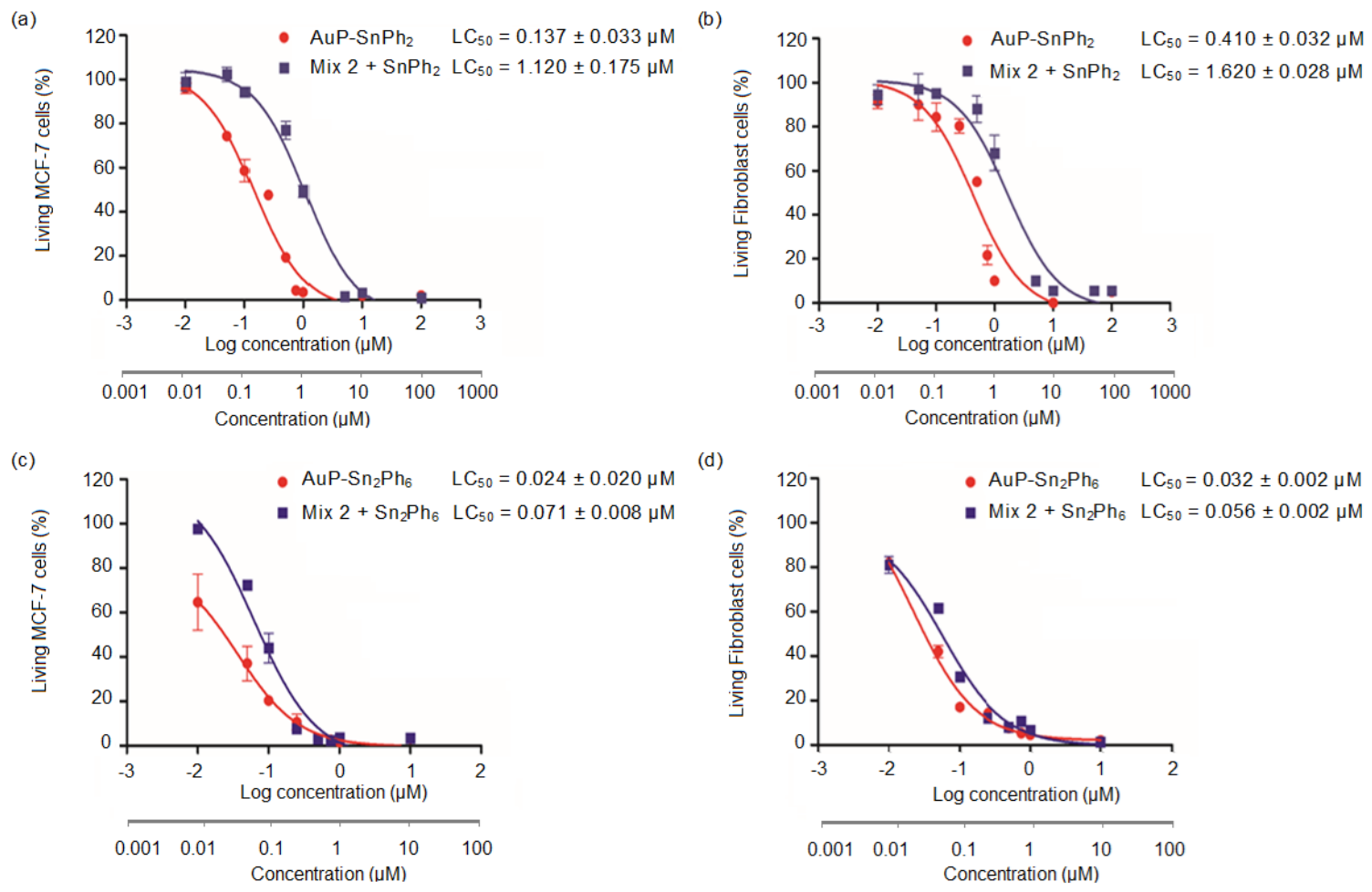

cancer or healthy cells (Fig 3a-d).

Figure 3. Cytotoxic study of AuP-SnPh and AuP-Sn ${ }_{2} \mathbf{P h}_{6}$ in comparison with $\mathbf{2}+\mathbf{S n P h}_{\mathbf{2}}$ and $\mathbf{2}+$ $\mathrm{Sn}_{\mathbf{2}} \mathrm{Ph}_{6}$, respectively. (a) Human breast cancer cells (MCF-7) and (b) healthy fibroblasts cells (FS 20-68) were incubated $72 \mathrm{~h}$ with increasing concentrations of AuP-SnPh $\mathbf{P h}_{\mathbf{2}}$ or $\mathbf{2}+\mathbf{S n P h}_{\mathbf{2}}$ and maintained in darkness. (c) Human breast cancer cells (MCF-7) and (d) healthy fibroblasts cells (FS 20-68) were incubated $72 \mathrm{~h}$ with increasing concentrations of AuP- 
$\mathrm{Sn}_{2} \mathrm{Ph}_{6}$ or $\mathbf{2}+\mathrm{Sn}_{2} \mathrm{Ph}_{6}$ and maintained in darkness. Values are means \pm standard deviations of 3 experiments.

These classical sigmoidal dose-response curves of cytotoxicity obtained when plotted as a logarithmic function of the concentration $(\mu \mathrm{M})$ permitted to determine drug concentrations leading to $50 \%$ cell mortality ( $\left(C_{50}\right)$ (Fig 3a-d). AuP-SnPh $\mathbf{P}_{\mathbf{2}}$ dyad exhibited a 3 folds lower $\mathrm{LC}_{50}$ on cancer cells $(0.137 \pm 0.033 \mu \mathrm{M})$ than on healthy cells $(0.410 \pm 0.032 \mu \mathrm{M})$, demonstrating a significant selectivity for cancer cells. The $\mathrm{LC}_{50}$ values showed also that on cancer cells, the toxicity of AuP-SnPh dyad was 9 fold higher $(0.137 \pm 0.033 \mu \mathrm{M})$ than equimolar mixture of its components (AuTPP-Malonic acid 2 and $\left.\mathbf{S n P h}_{2}\right)(1.120 \pm 0.175 \mu \mathrm{M})$. This underscored the potential of such association to develop metallodrugs in which the anticancer efficiency would be exacerbate.

When gold porphyrin $\mathbf{2}$ was functionalized with 2 tin residues to obtain $\mathbf{A u P -} \mathbf{S n}_{\mathbf{2}} \mathbf{P h} \mathbf{h}_{\mathbf{6}}$, we observed that this dyad was highly cytotoxic ( $\mathrm{LC}_{50}$ of $0.024 \pm 0.020 \mu \mathrm{M}$ on cancer cells) which is about 4 or 5 folds more potent than AuP-SnPh $\mathbf{P}_{\mathbf{2}}$ In addition, this dyad exhibited greater cytotoxicity than the equimolar mixture of its individual components (AuTPP-Malonic acid 2 and $\mathbf{S} \mathbf{n}_{\mathbf{2}} \mathbf{P h} \mathbf{h}_{\mathbf{6}}$ ). However, the selectivity towards cancer cells is lower than that of $\mathbf{A u P}-\mathbf{S n} \mathbf{P h} \mathbf{h}_{\mathbf{2}}$, since the AuP-Sn $\mathbf{P h}_{6} \mathrm{LC}_{50}$ on cancer cells $(0.024 \pm 0.020 \mu \mathrm{M})$ is quite similar to that on healthy cells $(0.032 \pm 0.002 \mu \mathrm{M})$. This strong toxicity, close between cancer and healthy cells is a real drawback for an eventual biomedical application in which the secondary effects of such a chemotherapy could be dramatic.

All together, these data demonstrated that $\mathbf{A u P}-\mathbf{S n P h}_{\mathbf{2}}$ dyad exhibited a higher toxicity against human breast cancer cells than healthy fibroblasts suggesting a stronger and specific effect on cancer cells. The cytotoxic potential of $\mathbf{A u P -} \mathbf{S n}_{\mathbf{2}} \mathbf{P h}_{6}$ dyad is 4 or 5 folds higher on breast cancer cells than that of AuP-SnPh $\mathbf{P}_{2}$, highlighting the advantage of the complexation with two tin cations instead of one, but this strong effect is counteracted with a loss of specificity toward cancer cells demonstrated by an elevated cell death level of healthy fibroblasts. Interestingly, the dyad $\mathbf{A u P -} \mathbf{S n}_{\mathbf{2}} \mathbf{P} \mathbf{P h}_{\mathbf{6}}$ is more than 35 times active than our previously reported best conjugates containing a gold porphyrin connected to a cis-platinum derivative. $^{29}$ 
In order to better understand this biological activity that we supposed to be due to the intrinsic toxicity of $\mathbf{S n}_{\mathbf{2}} \mathbf{P h} \mathbf{h}_{\mathbf{6}}$, we performed cytotoxicity experiments of all separated compounds on cancer and healthy cells (Figure 4a, b). As we can see, tin complexes (red and blue curves) were more cytotoxic than gold porphyrin $\mathbf{2}$ (green curves). In addition, in each cell line $\mathrm{Sn}_{2} \mathrm{Ph}_{6}$ exhibited the strongest cell death (blue curves).
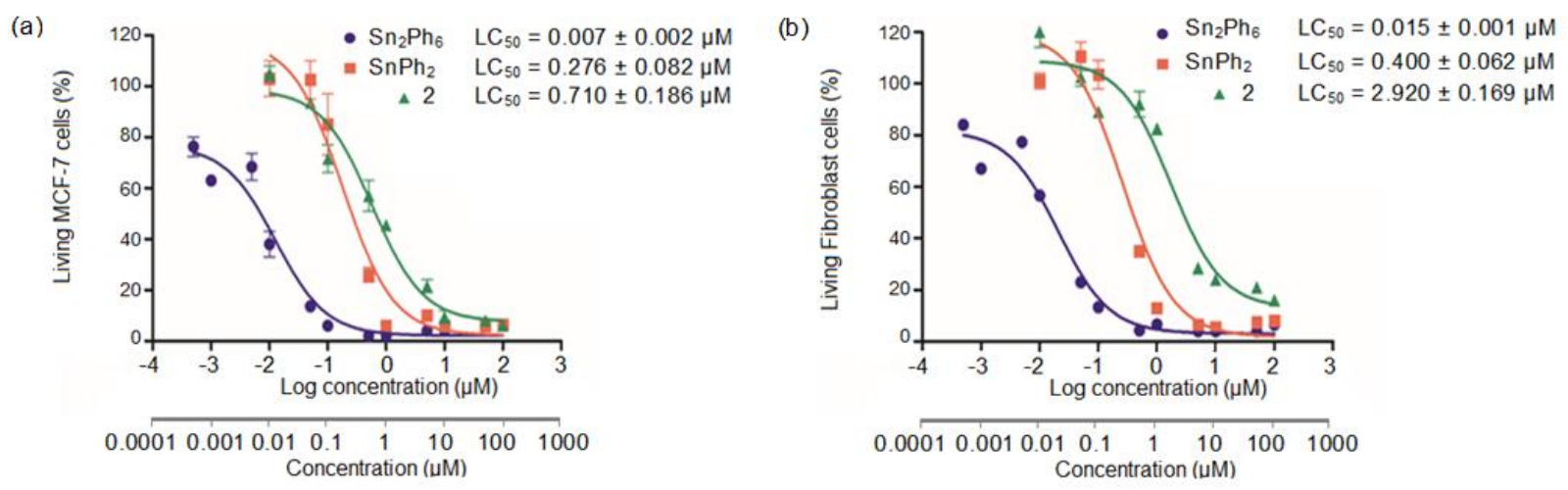

Figure 4. Cytotoxic study of $\mathrm{SnPh}_{2}, \mathbf{S n}_{\mathbf{2}} \mathbf{P h}_{6}$ and 2. (a) Human breast cancer cells (MCF-7) and (b) healthy fibroblasts cells (FS 20-68) were incubated $72 \mathrm{~h}$ with increasing concentrations of $\mathrm{SnPh}_{2}, \mathbf{S n}_{\mathbf{2}} \mathbf{P h}_{\mathbf{6}}$ and 2, and maintained in darkness. Values are means \pm standard deviations of 3 experiments.

The analysis of $\mathrm{LC}_{50}$ values confirmed that $\mathrm{Sn}_{2} \mathrm{Ph}_{6}$ was highly toxic for MCF-7 $(0.007 \pm 0.002$ $\mu \mathrm{M})$ and only two-fold less toxic on healthy fibroblasts $(0.015 \pm 0.001 \mu \mathrm{M})$. SnPh 2 exhibited a lower cytotoxic effect than $\mathbf{S n}_{2} \mathbf{P h}_{6}$, and the difference of this effect between cancer and healthy cells remains short $(0.276 \pm 0.082 \mu \mathrm{M}$ and $0.400 \pm 0.062 \mu \mathrm{M}$ for MCF-7 and FS 20-68, respectively). This suggested an absence of discrimination between cancer and healthy cells by tin complexes avoiding a biomedical application free from significant side effects. In contrast, the gold porphyrin 2 was clearly less efficient to kill cancer cells $(0.710 \pm 0.186 \mu \mathrm{M})$, but demonstrated a discrimination with healthy cells $(2.920 \pm 0.169 \mu \mathrm{M})$ in which cytotoxic effect was more than 4 times lower. The grafting of high efficient tin complexes with gold porphyrin 2, which is more apt to preferentially select cancer cells, is certainly a good strategy to obtain the best balance between efficiency and targeting on cancer cells.

In order to understand by which mechanism these dyads act on cancer cells, we performed a series of studies at the $\mathrm{LC}_{50}$ concentrations of both dyads, such as (i) flow cytometer to 
determine the modifications in cell cycle phases during treatment, (ii) detection of apoptosis using annexin $\mathrm{V}$ and (iii) cytoskeleton integrity via $\beta$-actin staining.
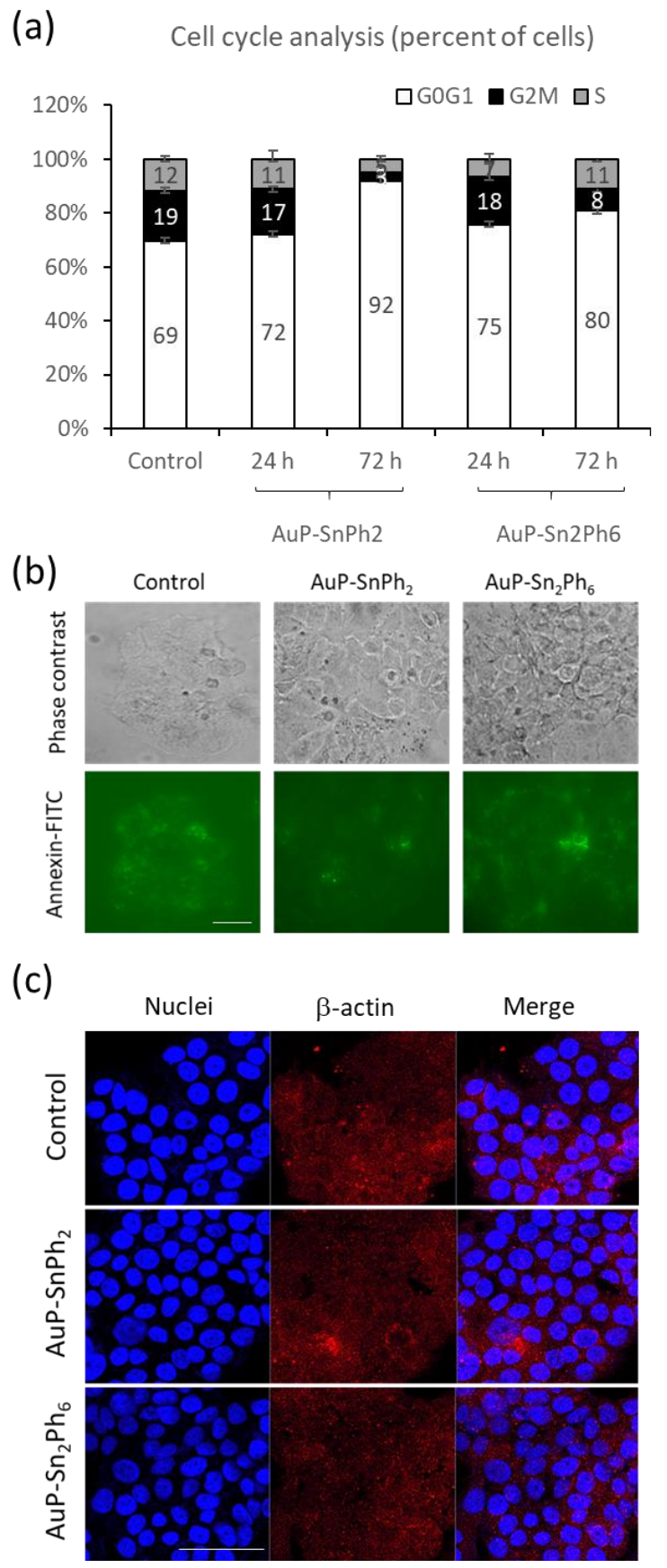

Figure 5. Mechanistic study of AuP-SnPh 2 and AuP-Sn $\mathbf{P h}_{6}$ cytotoxic effect. (a) Flow cytometer study after 24 and $72 \mathrm{~h}$ incubation with $\mathbf{A u P}-\mathbf{S n P h} \mathbf{P h}_{\mathbf{2}}$ and $\mathbf{A u P -} \mathbf{S n}_{\mathbf{2}} \mathbf{P h}_{\mathbf{6}}$ at their respective $\mathrm{LC}_{50}$ concentrations. Values are means \pm standard deviations of 2 experiments. (b) Annexin V-FITC staining for apoptosis markers detection after $72 \mathrm{~h}$ incubation time with 
dyads $\left(L C_{50}\right)$. (c) $\beta$-actin staining by immunofluorescence, for cytoskeleton integrity analysis after $24 \mathrm{~h}$ incubation time with dyads $\left(\mathrm{LC}_{50}\right)$.

It is well established that some chemotherapeutic agents are involved in interruption of the

cell cycle. ${ }^{41-42}$ Here we demonstrated that AuP-SnPh $\mathbf{2}$ and AuP-Sn $\mathbf{P h}_{\mathbf{6}}$ induced a $\mathbf{G}_{0} \mathbf{G}_{1}$ phase increase from $69 \%$ to $72 \%$ and $75 \%$ respectively, after only $24 \mathrm{~h}$ incubation time suggesting an arrest of cells in the quiescent state (Figure 5A). Importantly, $72 \mathrm{~h}$ incubation time of cells

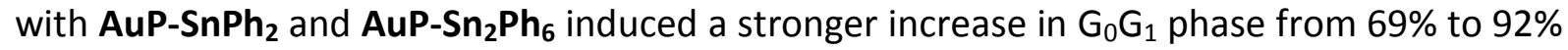
and $80 \%$, respectively. These data prove the arrest of cells before the restriction point avoiding the cell cycle entry.

We also performed in parallel, the analysis of the apoptotic marker annexin $\mathrm{V}$ level in MCF-7 cells, after AuP-SnPh $\mathbf{P}_{2}$ and $\mathbf{A u P}-\mathbf{S n}_{2} \mathbf{P h}_{6}$ treatment (Figure 5B). We noted no difference between expression of Annexin $\mathrm{V}$ between control and dyads treatment.

Finally, the effect of dyads was studied on the cytoskeleton of cells, by $\beta$-actin staining before and after dyads treatment (Figure 5C). Immunofluorescence experiment performed here did not show any alterations in the structural integrity of the cells.

Altogether these data highlight the blocking of cancer cells in the cycle phase before the entry in cell cycle, inducing the quiescence of the cells that is logically connected with an absence of apoptosis markers as shown by the same level of annexin V-FITC labeling between control and treated cells, and also with an absence in the cytoskeleton of cells.

\section{Conclusion}

For the first time, we report the synthesis and characterization of two new dyads consisting of gold porphyrin appended to phenyl tin malonate organometallic complexes. Their biological properties towards cancer and healthy cells were investigated and compared to the mixture of their corresponding individual components. The main finding of this work are: i) the dyads are more potent anticancer drugs than the mixture of their individual components. Therefore, the coordination of tin complex to the gold porphyrin induces a synergistic cytotoxic effect; ii) the dyad $\mathbf{A u P - S n P h}$ is an interesting anticancer metallodrug 
as it presents a very strong cytotoxicity and a good selectivity for cancer cells versus healthy cells; iii) AuP-Sn $\mathbf{P h}_{6}$ exhibits a very good anticancer activity with a higher $\mathrm{LC}_{50}$ than that of AuP-SnPh $\mathrm{P}_{2}$, but the presence of two tin units also induces a strong cytotoxic effect on healthy cells; iv) ultimately, tin complexes bring toxicity and the porphyrin brings more selectivity of cancer cells.

Overall, this study highlights the potential of the association of gold porphyrin with organotin compounds on anticancer therapy by acting on cell cycle and more particularly in blocking $\mathrm{G}_{0} \mathrm{G}_{1}$ phase inducing quiescence of cancer cells. Additional studies are in due course in our laboratory to establish the mechanism of action of these new metallodrugs and to improve the cancer cells selectivity of the most efficient dyads.

\section{Acknowledgments}

We thank Campus France (Eiffel grant), Région Pays de la Loire (LUMOMAT project), CNRS-L and the Lebanese University for the financial support of this project. The authors greatly acknowledge J. Hémez and L. Arzel (AMaCC platform, CEISAM UMR CNRS 6230, University of Nantes) for the mass spectrometry analyses.

\section{Experimental part}

\section{Synthesis of the compounds}

\section{Generalities}

${ }^{1} \mathrm{H}$ and ${ }^{119} \mathrm{Sn}\left\{{ }^{1} \mathrm{H}\right\}{ }^{24}$ spectra were recorded on an AVANCE 300 UltraShield BRUKER and AVANCE 400 BRUKER. Chemical shifts for ${ }^{1} \mathrm{H}$ spectra are referenced relative to residual proton in the deuterated solvent $\left(D_{M S O}-d_{6} \delta=2.50 \mathrm{ppm}\right.$ for $\left.{ }^{1} \mathrm{H}\right)$. NMR spectra were recorded at room temperature, chemical shifts are written in ppm and coupling constants in $\mathrm{Hz}$. Electrospray (ESI)-time of flight (TOF) mass spectrometry (MS) measurements were performed on a Xevo G2-XS QTOF spectrometer (Waters, USA) for ESI ${ }^{+}$and ESI'. 
Chemicals were purchased from Sigma-Aldrich or Alfa Aesar and used as received. Thin-layer chromatography (TLC) was performed on silica sheets precoated with Merck 5735 Kieselgel $60 \mathrm{~F}_{254}$. Column chromatography was carried out with Merck 5735 Kieselgel 60F (0.040-0.063 $\mathrm{mm}$ mesh). Compounds di-carboxymalonic acid p-cresol 1 ligand and porphyrin $\mathbf{2}$ were prepared according to literature procedures. $^{29}$

$\mathrm{SnPh}_{2}$. A solution of $150 \mathrm{mg}(0.23 \mathrm{mmol})$ in THF $(1 \mathrm{ml})$ was added dropwise to a solution of $\mathrm{SnPh}_{2} \mathrm{Cl}_{2} 81 \mathrm{mg}(0.23 \mathrm{mmol})$ in THF $(1 \mathrm{ml})$ at room temperature. The reaction was stirred for $20 \mathrm{~min}$, subsequently $\mathrm{NEt}_{3} 66 \mu \mathrm{l}(0.47 \mathrm{mmol})$ was added dropwise. The reaction was then stirred overnight. The solvent was evaporated and the residue was washed with water in order to remove triethylammonium salts. Yield: $71 \%(85 \mathrm{mg}) \cdot{ }^{119} \mathrm{Sn}\left\{{ }^{1} \mathrm{H}\right\}$ NMR $\left(\mathrm{THF}-\mathrm{d}_{8}, 400\right.$ $\mathrm{MHz}) \delta(\mathrm{ppm}):-172 .{ }^{1} \mathrm{H}$ NMR (DMSO-d $\left.6,300 \mathrm{MHz}\right) \delta(\mathrm{ppm}):$ 7.75-7.73 (d, 4H, $J=7.7 \mathrm{~Hz}$ ), 7.55-7.39 (m, 6H), 6.93-6.90 (d, 2H, J = 6.9 Hz), 6.23-6.20 (d, 2H, J = 6.2 Hz), $4.40(\mathrm{~s}, 1 \mathrm{H}), 2.16$ (s, 3H). HRMS (ES+) $[\mathrm{M}+\mathrm{Na}]^{+} \mathrm{m} / \mathrm{z}$ calcd for $\mathrm{C}_{22} \mathrm{H}_{18} \mathrm{O}_{5} \mathrm{SnNa}$ : 501.0064; found 501.0069 ( $\Delta=5$ ppm). Elem. Anal. Exp. C, 53.95; H, 6.41; N, 2.4. calc. C, 53.88; H, 6.33; N, 2.5.

$\mathrm{Sn}_{2} \mathrm{Ph}_{6}$. A solution of $130 \mathrm{mg}(0.14 \mathrm{mmol})$ in THF $(1 \mathrm{ml})$ was added dropwise to a solution of $\mathrm{SnPh}_{3} \mathrm{Cl} 110 \mathrm{mg}(0.28 \mathrm{mmol})$ in THF $(1 \mathrm{ml})$ at room temperature. The reaction was stirred for $20 \mathrm{~min}$, subsequently $\mathrm{NEt}_{3} 39 \mu \mathrm{l}(0.28 \mathrm{mmol})$ was added dropwise. The reaction was then stirred overnight. The solvent was evaporated and the residue was washed with water in order to remove triethylammonium salts. Yield: $93 \%$ (120 mg). ${ }^{119} \mathrm{Sn}\left\{{ }^{1} \mathrm{H}\right\}$ NMR (THF- $\mathrm{d}_{8}, 400$ $\mathrm{MHz}) \delta(\mathrm{ppm}):-226 .{ }^{1} \mathrm{H}$ NMR (DMSO-d $\left.6,300 \mathrm{MHz}\right) \delta(\mathrm{ppm}): 7.82-7.80$ (d, 4H, $J=7.8 \mathrm{~Hz}$ ), 7.68-7.65 (d, 8H, J = 7.6 Hz), 7.47-7.22 (m, 18H), 6.85-6.82 (d, 2H, J = 6.8 Hz), 6.44-6.41 (d, $2 \mathrm{H}, J=6.4 \mathrm{~Hz}), 4.67(\mathrm{~s}, 1 \mathrm{H}), 2.16(\mathrm{~s}, 3 \mathrm{H})$. Elem. Anal. Exp. C, 58.39; H, 5.8; N, 1.77. calc. C, 58.32; H, 5.7; N, 1.85 .

AuP-SnPh ${ }_{2}$. A solution of porphyrin $250 \mathrm{mg}\left(4.6 \times 10^{-2} \mathrm{mmol}\right)$ in THF $(2 \mathrm{ml})$ was added dropwise to a solution of $\mathrm{SnPh}_{2} \mathrm{Cl}_{2} 19.26 \mathrm{mg}\left(5.6 \times 10^{-2} \mathrm{mmol}\right)$ in THF $(1 \mathrm{ml})$ at room temperature. The reaction was stirred for $20 \mathrm{~min}$, subsequently $\mathrm{NEt}_{3} 13 \mu \mathrm{l}\left(9.3 \times 10^{-2} \mathrm{mmol}\right)$ 
was added dropwise. The reaction was then stirred overnight. The solvent was evaporated. The complex was dissolved in THF and precipitated in a saturated solution of $\mathrm{NaCl}$. The precipitated complex AuP-SnPh $\mathbf{2}_{\mathbf{2}}$ was filtered, washed with water and dried. Yield: 98\% (57 mg). UV-Vis $\left(\mathrm{CH}_{2} \mathrm{Cl}_{2}, \mathrm{~nm}\right) \lambda_{\max }\left(\log\right.$ Q $\left./ \mathrm{M}^{-1} \mathrm{~cm}^{-1}\right): 412$ (5.44); 532 (3.98). ${ }^{1} \mathrm{H}$ NMR (DMSO-d 6300 MHz): 9.34-9.28 (m, 8H), 8.29-8.27 (dd, 6H, J=1.1, 4.4 Hz), 8.03-7.90 (m, 15H), 7.42-7.27 (m, $8 \mathrm{H}), 3.48-3.46(\mathrm{t}, 1 \mathrm{H}, J=3.4 \mathrm{~Hz}), 3.27-3.25(\mathrm{~d}, 2 \mathrm{H}, J=3.2 \mathrm{~Hz}) . \mathrm{MS}(\mathrm{ES}+) \mathrm{M}^{+} \mathrm{m} / \mathrm{z}$ calcd for $\mathrm{C}_{60} \mathrm{H}_{40} \mathrm{~N}_{4} \mathrm{O}_{4} \mathrm{SnAu}: 1193.1733$; found 1193.1678 ( $\Delta=4.6$ ppm). Elem. Anal. Exp. C, 55.42; $\mathrm{H}$, 3.47; N, 4.12. calc. C, 55.85; H, 3.94; N, 4.34 .

AuP-Sn ${ }_{2} \mathrm{Ph}_{6}$. A solution of porphyrin $264 \mathrm{mg}\left(5.9 \times 10^{-2} \mathrm{mmol}\right)$ in THF $(2 \mathrm{ml})$ was added dropwise to a solution of $\mathrm{SnPh}_{3} \mathrm{Cl} 49 \mathrm{mg}\left(12 \times 10^{-2} \mathrm{mmol}\right)$ in THF $(1 \mathrm{ml})$ at room temperature. The reaction was stirred for $20 \mathrm{~min}$, subsequently $\mathrm{NEt}_{3} 17 \mu \mathrm{l}\left(11 \times 10^{-2} \mathrm{mmol}\right)$ was added dropwise. The reaction was then stirred overnight. The solvent was evaporated. The complex was dissolved in THF and precipitated in a saturated solution of $\mathrm{NaCl}$. The precipitated complex AuP-Sn $\mathbf{P h}_{\mathbf{6}}$ was filtered, washed with water and dried. Yield: $80 \%$ (90 mg). UV-Vis $\left(\mathrm{CH}_{2} \mathrm{Cl}_{2}, \mathrm{~nm}\right) \lambda_{\max }\left(\log\right.$ 目/ $\left./ \mathrm{M}^{-1} \mathrm{~cm}^{-1}\right): 412$ (5.45); 529 (4.11). ${ }^{1} \mathrm{H}$ NMR (DMSO-d 6300 MHz): 9.30-9.25 (m, 8H), 8.28-8.26 (dd, 6H, J = 1.2, 7.1 Hz), 8.12-7.68 (m, 25H), 7.42-7.37 (m, 18H). HRMS $\left(\right.$ ES $\left.^{+}\right)[M]^{+} \mathrm{m} / \mathrm{z}$ calcd for $\mathrm{C}_{84} \mathrm{H}_{60} \mathrm{AuN}_{4} \mathrm{O}_{4} \mathrm{Sn}_{2}: 1623.2272$, found $1623.2318 \mathrm{c}(\Delta=$ 4.6 ppm). Elem. Anal. Exp. C, 58; H, 4.08; N, 2.88. calc. C, 57.69; H, 4.26; N, 3.2.

\section{Biological experiments}

\section{Cell culture}

Human breast adenocarcinoma cells (MCF-7) (purchased from ATCC) were cultured in Dulbecco Eagle's Minimal Essential Medium (DMEM) supplemented with 10\% fetal bovine serum (FBS) and $1 \%$ penicillin/streptomycin (P/S). Adult Human Dermal Fibroblast cells (FS 20-68) were maintained in Roswell Park Memorial Institute (RPMI) medium supplemented with $10 \% \mathrm{FBS}$ and $1 \% \mathrm{P} / \mathrm{S}$. Both cell lines were allowed to grow in humidified atmosphere at $37{ }^{\circ} \mathrm{C}$ under $5 \% \mathrm{CO}_{2}$. For cytotoxic studies, the compounds (powder) are first diluted in DMSO at the concentration of $10 \mathrm{mM}$. Then, they are sonicated during 30 seconds and 
diluted at the required concentrations from 0.01 to $100 \mu \mathrm{M}$ in culture medium of each cell line.

\section{Cytotoxicity study}

MCF-7 and FS 20-68 cells were seeded into 96-well plates at a density of $10^{3}$ cells $/ \mathrm{cm}^{2}$. One day after, cells were incubated with or without different concentrations of compounds (from 0.01 to $100 \mu \mathrm{M}$ ) for 3 days. To quantify the percentage of living cells in each condition, cells were incubated $4 \mathrm{~h}$ with $0.5 \mathrm{mg} \mathrm{mL}^{-1}$ MTT (3-(4,5- dimethylthiazol-2-yl)-2,5-diphenyltetrazoliumbromide) in order to determine mitochondrial enzyme activity. Then, MTT precipitates were dissolved in ethanol/DMSO (1:1) solution and absorbance was measured at $540 \mathrm{~nm}$.

\section{Cell-cycle analysis}

Flow cytometric analysis was performed on MCF-7 cells seeded in 6-well plate and allowed to grow for $24 \mathrm{~h}$. Cells were then treated with dyads at their respective $\mathrm{LC}_{50}$ for 24 or $72 \mathrm{~h}$. After treatment cells were harvested and fixed with $70 \%$ ethanol overday. The fixed cells were then incubated with $10 \mathrm{mg} / \mathrm{mL}$ RNase $A$ and $1 \mathrm{mg} / \mathrm{mL}$ propidium iodide, in the dark, for $24 \mathrm{~h}$ at $4^{\circ} \mathrm{C}$. Finally, DNA content of the cells was analyzed using BD FACSCalibur flow cytometer.

\section{Immunofluorescent staining for $\beta$-actin detection.}

MCF-7 cells allowed to grow for $24 \mathrm{~h}$ on cover slips and were treated with or without dyads at their respective $L_{50}$ for $24 \mathrm{~h}$. Then cells were fixed using paraformaldehyde (PFA) $3.7 \%$ for $20 \mathrm{~min}$ and permeabilized using $0.2 \%$ Triton $\mathrm{X}-100$ for $4 \mathrm{~min}$ at room temperature. Actin was stained using a primary human anti-actin antibody (made from mouse) and an Alexa Fluor 568-conjugated anti-mouse antibody. Both of them were incubated $45 \mathrm{~min}$ at room temperature. Nuclei were counter-stained using Hoechst 33342. Representative images were obtained under Carl Zeiss confocal microscope, LSM 780.

\section{Annexin V detection}

MCF-7 cells allowed to grow for $24 \mathrm{~h}$ on cover slips and were treated with or without dyads at their respective $\mathrm{LC}_{50}$ for $72 \mathrm{~h}$. Cells were incubated with $5 \mu \mathrm{L}$ of annexin V-FITC (from 
abcam) for $5 \mathrm{~min}$, in darkness and room temperature. Then, cells were rinsed twice and fixed using PFA $2 \%$ for $20 \mathrm{~min}$. Representative images were obtained under fluorescent microscope Leica DM IRB.

\section{References}

1. T. C. Johnstone, K. Suntharalingam and S. J. Lippard, Chem. Rev., 2016, 116, 3436.

2. A. Leonidova and G. Gasser, ACS Chem. Biol., 2014, 9, 2180.

3. C. C. Konkankit, S. C. Marker, K. M. Knopf and J. J. Wilson, Dalton Trans., 2018, 47, 9934.

4. A. Rilak Simović, R. Masnikosa, I. Bratsos and E. Alessio, Coord. Chem. Rev., 2019, 398, 113011.

5. L. Zeng, P. Gupta, Y. Chen, E. Wang, L. Ji, H. Chao and Z.-S. Chen, Chem. Soc. Rev., 2017, 46, 5771.

6. D. R. van Staveren and N. Metzler-Nolte, Chem. Rev., 2004, 104, 5931.

7. L. Fernández-Vega, V. A. Ruiz Silva, T. M. Domínguez-González, S. Claudio-Betancourt, R. E. ToroMaldonado, L. C. Capre Maso, K. Sanabria Ortiz, J. A. Pérez-Verdejo, J. Román González, G. T. Rosado-Fraticelli, F. Pagán Meléndez, F. M. Betancourt Santiago, D. A. Rivera-Rivera, C. Martínez Navarro, A. C. Bruno Chardón, A. O. Vera and A. D. Tinoco, Inorganics, 2020, 8, 10.

8. Y. Geldmacher, M. Oleszak and W. S. Sheldrick, Inorganica Chim. Acta, 2012, 393, 84.

9. C. I. Yeo, K. K. Ooi and E. R. T. Tiekink, Molecules, 2018, 23, 1410.

10. S. K. Hadjikakou and N. Hadjiliadis, Coord. Chem. Rev., 2009, 253, 235.

11. I. Ott, Coord. Chem. Rev., 2009, 253, 1670.

12. T. Zou, C. T. Lum, C.-N. Lok, J.-J. Zhang and C.-M. Che, Chem. Soc. Rev., 2015, 44, 8786.

13. C.-M. Che, R. W.-Y. Sun, W.-Y. Yu, C.-B. Ko, N. Zhu and H. Sun, Chem. Commun., 2003, 1718.

14. R. W.-Y. Sun and C.-M. Che, Coord. Chem. Rev., 2009, 253, 1682.

15. R. W.-Y. Sun, C. K.-L. Li, D.-L. Ma, J. J. Yan, C.-N. Lok, C.-H. Leung, N. Zhu and C.-M. Che, Chem. Eur. J., 2010, 16, 3097.

16. D. Hu, Y. Liu, Y.-T. Lai, K.-C. Tong, Y.-M. Fung, C.-N. Lok and C.-M. Che, Angew. Chem., Int. Ed., 2016, 55, 1387.

17. C. T. Lum, R. Wai-Yin Sun, T. Zou and C.-M. Che, Chem. Sci., 2014, 5, 1579.

18. Y. Wang, Q.-Y. He, R. W.-Y. Sun, C.-M. Che and J.-F. Chiu, Cancer Res., 2005, 65, 11553.

19. C. N. Banti, S. K. Hadjikakou, T. Sismanoglu and N. Hadjiliadis, J. Inorg. Biochem., 2019, 194, 114.

20. M. G. Mirisola, A. Pellerito, T. Fiore, G. C. Stocco, L. Pellerito, A. Cestelli and I. Di Liegro, Appl. Organomet. Chem., 1997, 11, 499.

21. G. Basso, J. F. Cargnelutti, A. L. Oliveira, T. V. Acunha, R. Weiblen, E. F. Flores and B. A. Iglesias, J. Porphyr. Phthalocyanines, 2019, 23, 1041.

22. R. Rubbiani, W. Wu, A. Naik, M. Larocca, L. Schneider, R. Padrutt, V. Babu, C. König, D. Hinger, C. Maake, S. Ferrari, G. Gasser and B. Spingler, Chem. Commun., 2020, 56, 14373.

23. S. Gómez-Ruiz, G. N. Kaluđerović, S. Prashar, E. Hey-Hawkins, A. Erić, Ž. Žižak and Z. D. Juranić, J. Inorg. Biochem., 2008, 102, 2087.

24. G. N. Kaluđerović, H. Kommera, E. Hey-Hawkins, R. Paschke and S. Gómez-Ruiz, Metallomics, 2010, 2, 419.

25. F. A. Cotton and G. Wilkinson, Advanced Inorganic Chemistry, Wiley interscience, New York, 1995.

26. D. Thorpe, A. Callejas, D. Royzman, R. D. Pike, G. Eng and X. Song, J. Coord. Chem., 2013, 66, 3647.

27. M. K. Amir, S. Khan, R. Zia ur, A. Shah and I. S. Butler, Inorganica Chimica Acta, 2014, 423, 14.

28. S. Gómez-Ruiz, Ž. Žižak and G. N. Kaluđerović, Inorganica Chim. Acta, 2014, 423, 117.

29. I. Toubia, C. Nguyen, S. Diring, L. M. A. Ali, L. Larue, R. Aoun, C. Frochot, M. Gary-Bobo, M. Kobeissi and F. Odobel, Inorg. Chem., 2019, 58, 12395.

30. J. T. F. Lau, P.-C. Lo, W.-P. Fong and D. K. P. Ng, J. Med. Chem., 2012, 55, 5446.

31. P. D. Harvey, S. Tasan, C. P. Gros, C. H. Devillers, P. Richard, P. L. Gendre and E. Bodio, Organometallics, 2015, 34, 1218. 
32. A. Antipas, D. Dolphin, M. Gouterman and E. C. Johnson, J. Am. Chem. Soc, 1978, 100, 7705.

33. A. G. Davies, in Comprehensive Organometallic Chemistry II, eds. E. W. Abel, F. G. A. Stone and G. Wilkinson, Elsevier, Oxford, 1995, pp. 217.

34. G. B. Deacon and R. J. Phillips, Coord. Chem. Rev., 1980, 33, 227.

35. C. Anjorin, X. Song, D. Kumar, R. Pike, A. De Dios and G. Eng, J. Coord. Chem., 2010, 63, 4031.

36. X. Song, A. Zapata, J. Hoerner, A. C. de Dios, L. Casabianca and G. Eng, Appl. Organomet. Chem., 2007, 21, 545.

37. J. P. Costes, F. Dahan and J. P. Laurent, Inorganic Chemistry, 1985, 24, 1018.

38. V. Robert and G. Lemercier, J. Am. Chem. Soc, 2006, 128, 1183.

39. J. Holeček, A. Lyčka, K. Handlíř and M. Nádvorník, Czech. Chem. Commun., 1990, 55, 1193.

40. J. Otera, J. Organomet. Chem., 1981, 221, 57.

41. W. Zhuang, Z. Jia, H. Feng, J. Chen, H. Wang, Y. Guo and C. Meng, Biomed. Pharmacother., 2011, 65, 467.

42. J.-D. Liu, Y.-J. Wang, C.-H. Chen, C.-F. Yu, L.-C. Chen, J.-K. Lin, Y.-C. Liang, S.-Y. Lin and Y.-S. Ho, Mol. Carcinog., 2003, 37, 39. 